\title{
THE IN VITRO CULTURE OF RAT OVA
}

\author{
L. FOLSTAD, J. P. BENNETT AND R. I. DORFMAN \\ Department of Reproductive Physiology, Institute of Hormone Biology, \\ Syntex Research, Palo Alto, California, U.S.A.
}

\section{(Received 7th October 1968)}

Lewis \& Gregory (1929) were the first to culture the fertilized ovum of laboratory animals in vitro, using rabbit ova. Hammond (1949) cultivated 8-cell mouse ova to the blastocyst stage. This method was repeated and further developed by Whitten (1956), McLaren \& Biggers (1958), Tarkowski (1961) and Brinster (1963), among others. However, there have been no reported attempts to culture rat ova in vitro.

Ovum culture in the Sprague-Dawley rat was developed in our laboratory to test the viability of ova recovered from rats previously treated with antifertility compounds. The method was also required for the in vitro testing of such compounds upon rat ova with or without subsequent transfer to recipient rats.

Attempts were made to culture 2-, 4- and 8-cell rat ova using various media, energy and nitrogen sources, and several tissue culture systems. The successful culture of rat ova, from the 8-cell to blastocyst stage, was achieved using the method of Brinster (1963), with sodium pyruvate and lactate as the energy source and with bovine serum albumin as the source of nitrogen (Thomson, 1966).

The 8-cell ova were recovered from rats on the 4th day of pregnancy (first day $=$ day of observing spermatozoa in the vaginal lavage), by flushing them from the reproductive tract with the culture medium delivered from a 30-gauge blunt-ended needle attached to a $1-\mathrm{ml}$ syringe. Sterile technique was used throughout the ovum-recovery procedure.

The ova were carefully scrutinized beneath the microscope and any morphologically abnormal ova were rejected. The remaining ova were transferred to the culture medium using a disposable micro-pipette (Drummond, Broomall, Penn.) attached to a Hamilton microsyringe. The culture system consisted of small drops $(0 \cdot 1 \mathrm{ml})$ of the Brinster medium under sterile equilibrated mineral oil contained in plastic petri dishes of $6 \mathrm{~cm}$ diameter. The dishes containing the ova were incubated at $37^{\circ} \mathrm{C}$ in a humidified atmosphere of $5 \%$ carbon dioxide. Twenty-four hours later the cultured ova were examined, using an inverted Plankton microscope (Carl Zeiss) to determine the number of cells or to observe the presence of blastocysts.

In seven consecutive experiments, 197 morulae or blastocysts were produced from 219 ova (Plate 1). None of the cultured blastocysts lost the zona pellucida, as do mouse ova in culture. Continued culture of the rat blastocysts for up to 3 days after the initial $24 \mathrm{hr}$ still showed the zonae intact. 
Attempts are being made to test the viability of the cultured ova by transferring them to the uteri of rats on the 4th day of pseudopregnancy. Preliminary results of six experiments indicate that the cultured ova will progress to mature

TABLE 1

THE IN VITRO CULTURE OF 8-GELL RAT OVA TO MORULAE OR BLASTOCYSTS

\begin{tabular}{|c|c|c|c|c|c|}
\hline \multicolumn{3}{|c|}{ No. of ova } & \multirow{3}{*}{$\begin{array}{c}\% \text { ova } \\
\text { successfully } \\
\text { cultured } \\
(B / A \times 100)\end{array}$} & \multirow{2}{*}{\multicolumn{2}{|c|}{$\begin{array}{c}\text { No. of ova } \\
\text { developed into: }\end{array}$}} \\
\hline \multirow{2}{*}{$\begin{array}{l}\text { Recovered } \\
\text { from donor } \\
\text { rats }\end{array}$} & \multirow{2}{*}{$\begin{array}{c}\text { Cultured } \\
\text { in vitro } \\
(A)\end{array}$} & \multirow{2}{*}{$\begin{array}{l}\text { Progressed } \\
\text { in culture } \\
\qquad(B)\end{array}$} & & & \\
\hline & & & & Morulae & Blastocysts \\
\hline $\begin{array}{l}42 \\
36 \\
62 \\
61 \\
24 \\
50 \\
34\end{array}$ & $\begin{array}{l}38 \\
23 \\
54 \\
35 \\
15 \\
38 \\
16\end{array}$ & $\begin{array}{l}33 \\
18 \\
48 \\
30 \\
15 \\
37 \\
16\end{array}$ & $\begin{array}{r}87 \\
78 \\
89 \\
86 \\
100 \\
97 \\
100\end{array}$ & $\begin{array}{l}9 \\
= \\
\\
9 \\
3\end{array}$ & $\begin{array}{l}24 \\
18 \\
48 \\
30 \\
15 \\
28 \\
13\end{array}$ \\
\hline $\begin{array}{l}\text { Total } \\
309\end{array}$ & 219 & 197 & 90 & 21 & 176 \\
\hline
\end{tabular}

foetuses after transfer. Further work is being done with the in vitro culture of 2- and 4-cell ova in the rat. Studies have also begun on the effects of various steroids and antifertility compounds upon rat ova using in vitro culture and ovum transfer techniques.

\section{REFERENCES}

Brinster, R. L. (1963) A method for in vitro cultivation of mouse ova from two-cell to blastocyst. Expl Cell Res. 32, 205.

Hammond, J., JR (1949) Recovery and culture of tubal mouse ova. Nature, Lond. 163, 28.

LEWIS, W. H. \& GREGORY, P. W. (1929) Cinematographs of living developing rabbit eggs. Science, N.r. $69,226$.

McLaren, A. \& Biggers, J. D. (1958) Successful development and birth of mice cultivated in vitro as early embryos. Nature, Lond. $182,877$.

TARkowski, A. K. (1961) Mouse chimaeras developed from fused eggs. Nature, Lond. 190, 857.

Thosson, J. L. (1966) Effect of inhibitors of carbohydrate metabolism on the development of preimplantation mouse embryos. Expl Cell Res. 46, 252.

Whitten, W. K. (1956) Culture of tubal mouse. Nature, Lond. 177, 96. 
PL.ATE 1
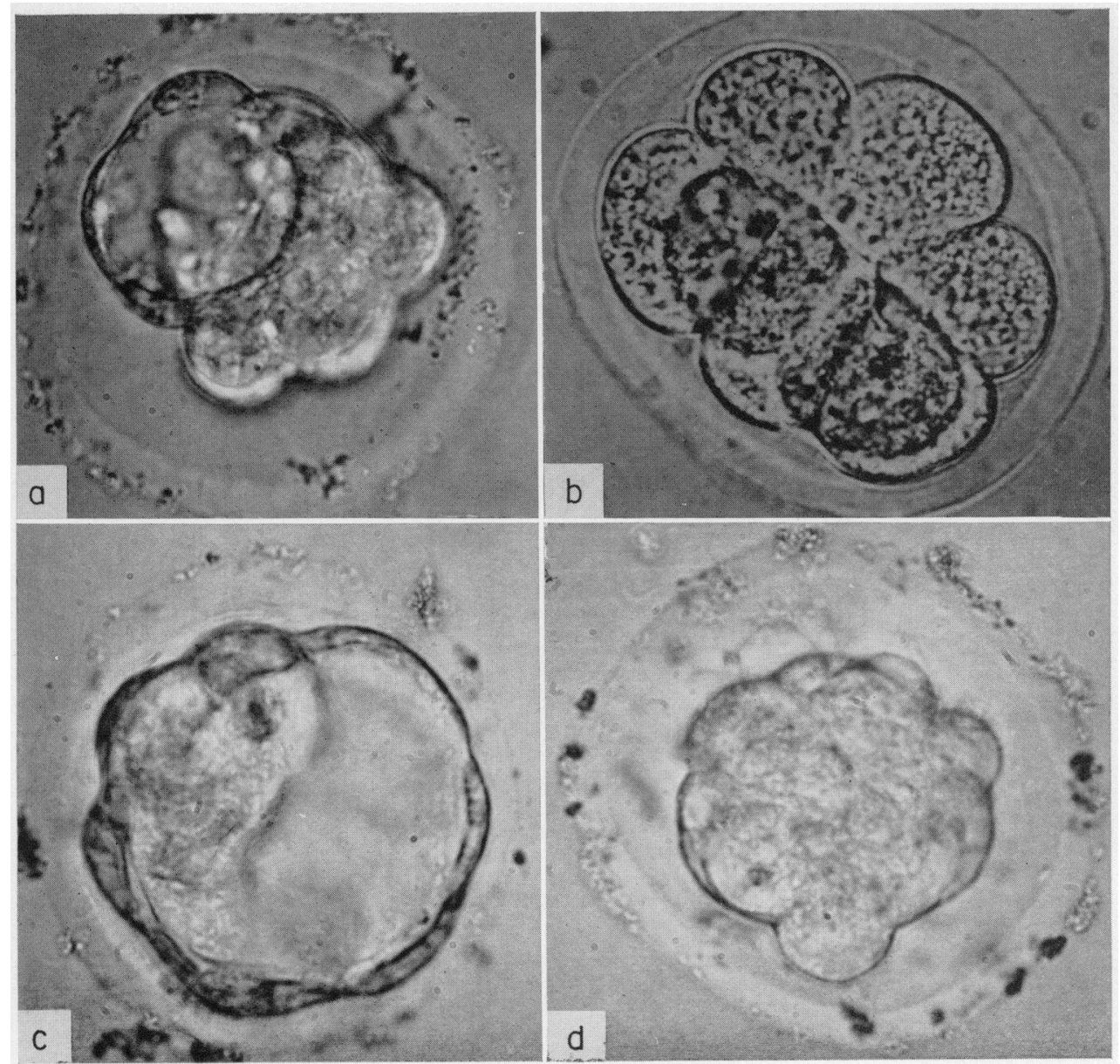

The growth of an 8-cell rat ovum (a) through morula (b) and carly blastocyst (c) to the blastocyst stage (d) during in ritro culture. $\times 700$. 